\title{
Translating Tourism Texts in the Light of the Skopos Theory ${ }^{*}$
}

\author{
WANG Xiao-yan \\ Changchun University, Changchun, China
}

\begin{abstract}
The present paper aims to explore the activity of translating Chinese tourism texts into English within the framework of the skopos theory, with two culture-related tourism texts in China as examples. First, the basic principles of the skopos theory are outlined, followed by discussion of their application in translating tourism texts. An attempt is then made to analyze two types of translation errors in English translations of tourism texts. They are cultural translation errors and pragmatic translation errors. The paper concludes with two approaches to solve the problems. One of the them is to enhance translators' awareness of applying skopos to translation. Another is to enhance the translators' bilingual abilities and ethical standards.
\end{abstract}

Keywords: skopos theory, tourism texts, translating

\section{Introduction}

Since the initiation of the reform and opening-up in 1978, China has shown eagerness to introduce itself to the world, thus creating a big market for pragmatic translation. And tourism texts translation, which refers to the translation of places of historic interest and scenic beauty, is one of the important parts of it. Since this kind of translation serves a function or purpose quite different from that of literary texts, they are often defined as "pragmatic" or "non-literary" texts (Reiss, 1989, p. 106). The past two decades have seen a dramatic increase in market demand for non-literary translation worldwide, which has led to intense research activities in the field. However, the ever-increasing translation of non-literary texts in the past three decades has not brought about much improvement in translation quality. As noted by some researchers (DING, 2002; XIAO, 2011), the number of various translation errors and mistakes in English translations of tourism texts is amazingly large. Since the skopos theory meets the growing need for non-literary translation in the latter half of the twentieth century (Schäffner, 1998, p. 235), some Chinese authors (ZHANG, 2005; LIN, 2006) have applied the theory in their discussion of translation mistakes and translation methods in handling non-literary texts. Based on their former study, this paper, drawing on the skopos theory, including Nord's functional classification of translation errors, examines two translation errors in English translations of Chinese tourism texts and suggests solutions to the existing problems.

\section{The Skopos Theory and the Translation of Tourism Texts}

The skopos theory was developed in Germany in the late 1970s. It reflects a general shift from linguistic and

\footnotetext{
*Acknowledgements: This paper is one of the result of the author's research programs "The Study of Pragmatic Translation Teaching in the Light of Skopos”.

WANG Xiao-yan, associate professor, School of Foreign Languages, Changchun University.
} 
formal translation theories to a more functionally and socio-culturally oriented concept of translation. Initially formulated by Reiss in the 1970s, the theory was enunciated by Vermeer in the 1980s, and was further developed in the 1990s by Nord. The basic principles of the skopos theory are summarized as follows:

Any form of translational action may be conceived as a "purposeful activity" (Nord, 1997, p. 12). The action should observe the "skopos rule", which postulates that the form of a TT (target text), including translation strategies and methods adopted, should above all be determined by the purpose or skopos that the TT is intended to fulfil in the target context. Every translation presupposes a commission and is carried out according to a skopos or commission, which is largely determined by the commissioner or client. The skopos of the TT and the mode in which it is to be realized are negotiated between the commissioner and the translator. The translator as the "expert” in translational action is responsible for the final translation (Vermeer, 2000, p. 221-230). Translation is the production of a functionally appropriate TT based on a ST (source text). While the translator is entitled to decide what role an ST plays in the translation process, the decisive factor is the precisely specified skopos. The ST is only one constituent of the commission and an "offer of information".

The theory calls for redefining the relationship between ST and TT. Since a tourism text usually focuses on content rather than on its form, the translator should transmit the ST's conceptual content and does not have to preserve the ST's linguistic form or original style insofar as the TT fulfils its intended skopos or function. On the other hand, a tourism text is usually written originally for a source-culture situation, and in most cases its author lacks the necessary knowledge of the target culture and its texts. Consequently, the content, form or skopos of the ST may not suit the target context and the target addressees with their culture-specific world knowledge, expectations, and communicative needs (Nord, 1997, p. 13). Where the TT's skopos disagrees with that of the ST, the translator should not stick to the ST; rather he/she should produce a functionally appropriate TT based on the ST.

\section{Translation Error Analysis}

\section{Cultural Translation Errors}

Cultural translation errors are related to the question of whether or not source-culture conventions should be adapted to target-culture standards. Since the skopos theory is basically a "target text-oriented paradigm" (Toury, 1995, p. 25) and "adaptation of the source text to target-culture standards is a procedure that is part of the daily routine of every professional translator” (Nord, 1997, p. 28). So cultural translation errors usually refer to the cases where the TT conflicts with the target-culture customs and conventions. As a result, the target readers might find the transmitted message incomprehensible or unacceptable, which prevents the TT from achieving its intended skopos and function (see Example 1).

Example (1) ST: 长春市地处中国东北部, 是吉林省省会 , 曾先后被评为中国优秀旅游城市、国家环 保模范城市、国家卫生先进城市、国家园林城市和全国创建文明城市先进单位。

TT: Changchun located itself in China's Northeast. It is the capital city of Jilin Province. Changchun is one of China's authorized excellent tourist cities. It is also a national model city in terms of environmental protection, a national sanitary advanced city, a national garden-like city, and a national city advanced in the building of cultural and ideological progress.

In Example 1, the underlined parts are packed with high-sounding formulaic expressions. Natural and 
sometimes even "pleasing" as they may sound to the Chinese ear, these Chinese culture-specific clichés, if rendered literally, can be perceived as pretentious by the target audiences steeped in a vastly disparate cultural context (DING, 2002, p. 46). The translator's failure to adapt these high-sounding phrases to the target-culture customs causes the following cultural translation errors: (1) the "faithful" translation of the formulaic language creates a strong sense of monotony and pretentiousness, and an English audience might find it repulsive; (2) the added word "authorized" will render target readers perplexed as the concept “被批 准为” (approved, sanctioned, or authorized) reflects the contemporary Chinese institutional culture. So we can just omit the word “authorized”; (3) the collocation a national... advanced city (国家…先进城市) appears outlandish to target addressees as this strictly literal rendering does not conform to standard English usage; and (4) the gerundial phrase building of cultural and ideological progress (创建文明) makes virtually no sense to native speakers of English.

Cultural translation errors are due to the translator's "inadequate decision with regard to reproduction or adaptation of culture-specific conventions” (Nord, 1997, p. 75). This "inadequate decision” is often attributable to fact that the translator ignores the culture-specific knowledge, needs and expectations of the target audience, which in turn results from an insufficient awareness of the TT's function or skopos.

\section{Pragmatic Translation Errors}

Pragmatic translation errors are caused by inadequate solutions to pragmatic translation problems such as a lack of receiver orientation. The consequence of such errors is that the target audiences tend not to realize that they are getting irrelevant or insignificant information. However, it is not very difficult to solve pragmatic translation problems "once they have been identified as problems". Normally they can be identified only by a competent person comparing the ST with its TTs in the light of the translation brief (Nord, 1997, p. 76). Pragmatic translation errors often crop up in the following situations: some significant, relevant, or potentially important information in the ST is not expressed as shown in the following example (see Example 2):

Example (2) ST: 由潘鹤教授涉及的贺龙元帅铜像，屹立在天子山贺龙公园。铜像高6.5米，重约100 吨。

TT1: The Grand Bronze Statue of Marshal He Long, designed by Professor Pan He, is standing in He Long Park. The Statue is 6.5 metre in height, and 100 ton in weight.

TT2: The Grand Bronze Statue of Marshal He Long, designed by Professor Pan He, is standing in He Long Park. The Statue is 6.5 metre in height, and 100 ton in weight. He Long (1896-1969), one of the founders of the People's Republic of China, born in Sangzhi, somewhat 60 kilometres from the tourist site, led many battles during the Chinese Civil War and Anti-Japanese War.

TT1, lacked the receivers' orientation. They just got the rather insignificant information: the height and weight etc., of the statue, which are obviously standing there. In fact the sculptor's name sometimes is not necessary to mention unless he/she is world famous one. Truly, almost all the Chinese people know who He Long is. Yet the target readers do not know, so what the tourists most interested in is "who is He Long?" Why the statue was standing here? The translator should include relevant background information in the translation so as to bridge the "information gap" for the target reader. TT2 answered the questions in the light of skopos theory. Transliterating plus the cultural information is easy for the target readers. 
The obvious reason for these pragmatic errors is that the translators fail to distinguish ST audiences from TT audiences with their different culture-specific world knowledge, expectations, and communicative needs. Nord (1997) rightly maintained that the importance of the audience is frequently neglected in translation practice and that "the adaptation of precisely these elements is of particular importance" (p. 52).

\section{Approaches to Existing Problems}

\section{Enhance Translators’ Awareness of Applying Skopos Theory to Translation}

The skopos theory recognizes the translator as both the expert and the TT's ultimate producer directly responsible for the final product (Vermeer, 2000, p. 231). As analyzed above, pragmatic, cultural, and translation errors are often due to translators' poor awareness of the TT's skopos and its target readers. If they have such kind of awareness, if they know that "he end justifies the means" (XIE, 2008, p. 135), sometimes the errors discussed above, can be easily avoided. So instead of teaching and applying linguistic translation theories to translation, programs of skopos theory of translation should be opened in colleges and other translation courses. Such programs will be specially designed to enhance peoples' awareness of applying skopos theory to their translation practice in order to meet the great demands of translation markets nowadays. Translation studies scholars and veteran translators will be invited to give people talks or keynote presentations on the theory which are to be attended by translators, clients, teachers, students, and the general public interested in such events.

Furthermore, according to skopos theory, in order to know the purpose of the translation, a translator has to have a strong sense of cooperation with the clients. To promote communication and cooperation between clients and translators, one important move is to organize "commissioner and translator" workshops. In this way, translators' awareness of applying skopos theory to translation will be aroused.

\section{Enhance Translators' Bilingual Abilities and Ethical Standards}

Some of the linguistic errors are often due to translators' inadequate linguistic abilities and low ethical standards. Given the various translation errors they have made, many translators are not worthy of the title "expert" and should in fact be placed on a probationary period. To raise the overall quality of practitioners and turn out high-calibre translators, it is suggested that a great amount of practice should be made. And translators should read a lot and know something about everything, especially about culture. It is suggested that National Accreditation Authority for Translators should be established in China. This government agency aims to establish and maintain translation standards throughout the country. Apart from accreditation of translators, it can run various workshops for candidates wishing to obtain accreditation and provide tailor-made training programs for practicing translators. Such programs will be specially designed to enhance translators' awareness of skopos, bilingual abilities, and ethical standards.

\section{Conclusions}

This paper has attempted to elaborate on the following points: (1) The skopos theory lends itself particularly well to translating non-literary texts; (2) Tourism texts perform primarily an informative function with a secondary operative function; (3) Pragmatic and cultural translation errors are often due to the translators' poor awareness of the TT's skopos and its target readers; (4) In many cases, the client or commissioner should be held partly responsible for translation errors; and (5) Two approaches, which involve the general public, the 
commissioner, and the translator respectively, might help resolve the existing problems. Although the findings need to be further substantiated by looking at more data in terms of tourism texts, it is hoped that this study can make people rethink pragmatic translation and translator training as well. On the other hand, the skopos theory itself opens avenues for further investigation and its potential has yet to be exploited. Specifically, the various ways in which the skopos theory can guide and benefit the translation community, including clients and practicing translators, should be investigated more deeply and extensively.

\section{References}

DING, W. Q. ( 2002). English publicity texts needs improving. Chinese Translators Journal, 4, 44-46.

LIN, X. Q. (2006). Employment of the functional concept in the Chinese-English translation of tourist materials. Journal of Fujian Normal University, 2, 135-140.

Nord, C. (1997). Translating as a purposeful activity: Functionalist approaches explained. Manchester: St. Jerome.

Reiss, K. (1989). Text types, translation types and translation assessment. Readings in translation theory (pp. 105-115). Helsinki: Oy Finn Lectura Ab.

Reiss, K., \& Vermeer, H. J. ( 1984) Grundlegung einer allnemeinen translationstheorie. Tübingen: Niemeyer.

Schäffner, C. (1998). Skopos theory. Routledge Encyclopedia of Translation Studies (pp. 235-238). London \& New York: Routledge.

Toury, G. (1995). Descriptive translation studies and beyond. Amsterdam: John Benjamins.

Vermeer, H. J. (2000). Skopos and commission in translational action. The Translation Studies Reader (pp. 221-233). London: Routledge.

XIAO, Y. M. (2011). The translation of tourism texts under the guidance of skopos theory. Academic Research, (3).

XIE, T. Z. ( 2008). Contemporary foreign translation theories (pp. 135-157). Tianjin: Nankai University Press.

ZHANG, M. F (2005). Function plus loyalty: On Nord's functionalist approach to translation. Journal of Foreign Languages, 1, 60-65. 